\title{
PERMASALAHAN PERMUKIMAN LIAR DI DUSUN IV LAMTORO II RT. V DESA BANDAR KLIPPA, KECAMATAN PERCUT SEI TUAN, KABUPATEN DELI SERDANG, SUMATERA UTARA
}

\author{
Mona Adria Wirda', M. Rizky Akbar², Rajul Munawar², Riki Rahmad' \\ 'Dosen Jurusan Pendidikan Geografi Fakultas Ilmu Sosial Universitas Negeri Medan \\ ${ }^{2}$ Mahasiswa Jurusan Pendidikan Geografi Fakultas IImu Sosial Universitas Negeri Medan \\ Jl. Willem Iskandar Psr V Medan Estate Medan, 20211 Indonesia \\ Email: monaadria@unimed.ac.id
}

\begin{abstract}
Abstrak:
Penelitian ini bertujuan untuk mengetahui : (1) Legalitas lahan di Dusun IV Lamtoro II RT. V Desa Bandar Klippa Kecamatan Percut Sei Tuan, (2) Kualitas fisik permukiman di Dusun IV Lamtoro II RT. V Desa Bandar Klippa Kecamatan Percut Sei Tuan. Penelitian ini dilakukan di di Dusun IV Lamtoro II RT. V Desa Bandar Klippa Kecamatan Percut Sei Tuan. Populasi dalam penelitian ini adalah Dusun IV Lamtoro II RT. V Desa Bandar Klippa Kecamatan Percut Sei Tuan.Teknik pengambilan sampel adalah dengan mengambil $10 \%$ dari jumlah KK yang bermukim disana. Teknik analisis data yang digunakan dalam penelitian ini adalah teknik analisis deskriptif kualitatif yaitu mengumpulkan, menganalisis menafsirkan serta memberikan penilaian terhadap kondisi fisik wilayah yang dikategorikan kedalam tiga kategori yaitu Permukiman Elit, Perkampungan Kota, dan Permukiman Kumuh. Faktor pendorong masyarakat bertempat tinggal di lokasi permukiman liar disebabkan oleh beberapa faktor diantaranya kepadatan penduduk yang tinggi sehingga banyak masyarakat yang tidak dapat untuk membangun rumah dikarenakan lahan yang tidak memadai dan memilih untuk membangun rumah di lahan illegal milik pemerintah tersebut.Kemudian dengan harga lahan yang murah menyebabkan banyak masyarakat yang tergiur untuk membelinya dan tidak mementingkan lahan itu illegal dan membangunnya untuk dijadikan tempat tinggal. Selain itu masih banyak masyarakat yang kurang mampu tidak mampu untuk mengontrak rumah di daerah kota karena harga sewa yang semakin tinggi sehingga mencari rumah kontrakan di permukiman liar dikarenakan harga sewa yang murah. Berdasarkan kualitas rumah dan lingkungan, maka di daerah Dusun IV Lamtoro II RT. V terdapat 15 dari 30 rumah dengan golongan Perkampungan Kota serta 15 dari 30 rumah dengan golongan Permukiman Kumuh.
\end{abstract}

Kata kunci : permukiman liar, legalitas lahan, kualitas fisik

\section{PENDAHULUAN}

Geografi Pembangunan sangat penting untuk dipelajari dalam rangka mensukseskan pembangunan. Karena setiap perencanaan yang akan dilakukan oleh ahli-ahli planologi harus selalu mempertimbangkan aspek geografinya. Aspek itu antara lain aspek fisik seperti tanah, daerah perairan, iklim dan lain-lain. Aspek manusiawi atau aspek social seperti jumlah penduduk, pertumbuhan penduduk, penyebaran dan lain-lain.Aspek biotis seperti hewan dan tanaman.Serta aspek abstrak yang meliputi letak, luas, batas dan bentuk ruang.Agar tujuan pembangunan dapat dicapai maka harus ada kerjasama yang baik antara keduanya.

Dapat kita lihat bahwa dari tahun ke tahun ilmu geografi semakin berperan dalam pembangunan mulai dari awalnya orang-orang tidak mengetahui dan mengabaikan keterbelakangan sampai pada akhirnya orang menyadari pentingnya spasial dan penelitian tentang kebijakan perencanaan pembangunan yang berorientasi pada aspek geografi pun diperhatikan sehingga pada akhirnya geografi merupakan ilmu yang interdisipliner terhadap masalah-masalah pembangunan dan keterbelakangan. 
Masalah permukiman dipelajari dalam ilmu geografi yang berwujud sebagai studi Geografi Pemukiman. Berdasarkan pendekatan structural, geografi permukiman termasuk dalam cabang geografi manusia. Geografi manusia mempelajari aspek keruangan gejala di permukaan bumi yang mengambil manusia sebagai objek pokok, yang didalamnya termasuk aspek kependudukan, aspek aktivitas sosial ekonomi dan aktivitas politik (Hadisumarno:1985). Jadi pembahasan tentang pemukiman tidak terlepas dari disiplin ilmu geografi manusia yang secara mendalam dipelajari dalam geografi permukiman yang mencakup kedalam geografi pembangunan.

Permukiman dalam arti sempit adalah rumah atau tempat tingal atau bangunan tempat tinggal, sedangkan dalam arti luas adalah perihal tempat tinggal atau segala sesuatu yang berkaitan dengan tempat tinggal. Yunus (1987) mendefinisikan pengertian permukiman dalam geografi sebagai bentukan natural (alami) maupun artifisial (buatan) dengan segala kelengkapannya yang dipergunakan oleh manusia, baik secara individu maupun kelompok untuk bertempat tinggal, baik sementara maupun menetap dalam rangka menyelenggarakan kehidupannya.

Pemukiman buatan pada saat ini lebih ditekankan yang mana secara kontiniu eksistensinya dapat digolongkan menjadi pemukiman perkotaan (urban settlement) dan permukiman perdesaan (rural settlement) Yunus (1987).

Jaringan jalan merupakan kunci dalam usaha perencanaan pembuatan komplek perumahan. Adanya jalur jalan akan mengatur letak segala kegiatan yang terdapat pada komplek perumahan (Judohusodo, 1991), hal ini mengakibatkan bahwa harga tanah yang tinggi umumnya merupakan daerah yang mempunyai aksesibilitas tinggi dengan fasilitas umum yang memadai, yang secara spatial dekat dengan jalan aspal. Kurang memadainya fasilitas umum terutama jalan dapat mengakibatkan letak persebaran rumah menjadi tidak teratur.

Daerah perumahan yang

berkembang secara alami tanpa adanya perencanaan yang baik dapat mengakibatkan letak perumahan menjadi tidak teratur.Tidak teraturnya letak ini dapat berkembang menjadi daerah kumuh. Menurut Bintarto (1984), daerah kumuh merupakan daerah yang tidak teratur dan bangunan-bangunan yang ada tidak memenuhi persyaratan bangunan dan kesehatan. Munculnya daerah kumuh ini akibat langsung pertumbuhan penduduk serta perpindahan penduduk dari desa ke kota dengan kualitas diri yang rendah baik dari petunjuk tentang rendahnya kualitas yang sering terjadi pada daerah padat penduduk.Lain halnya dengan daerah perkotaan maka di daerah pedesaan, penduduk desa yang semakin berjubel mengakibatkan terjadinya pendesakan lahan-lahan yang seharusnya tidak digunakan untuk pemukiman (misalnya: hutan-hutan di lereng pegunungan, lahanlahan disekitar pantaiatau di tempattempat lain) sehingga makin lama eksploitasi sumber alam akan terjadi tanpa kendali dengan akibat kerusakan pada sistem ekologinya. Apabila pada daerah perkotaan kita melihat kekurangan lahan untuk tempat tinggal, ditambah lagi adanya proses pengisianpada perkampungan yang berjalan terusmenerus yang pada akhirnya mengakibatkan terciptanya deteriorisasi lingkungan tempat tinggal, maka di daerah pedesaan agak sedikit berbeda. Penambahan bangunan-bangunan juga terjadi di daerah permukiman perdesaan, tetapi berhubung tersedianya lahan masih cukup leluasa untuk maksud-maksud tersebut dibanding dengan daerah perkotaan, maka sebenarnya untuk menciptakan suasana tata ruang yang layak untuk pemukiman masih banyak kesempatan.

Permukiman liar dapat diartikan sebagai tempat tinggalatau bermukim suatu penduduk yang didirikan secara tidak sah 
menurut hukum (ilegal), baik terhadap tanah milik orang lain maupun milik negara. Pengenalan permukiman liar selalu terikat dengan legalitas lahan dimana bangunan akan dibangun, sedangkan pengenalan permukiman kumuh selalu dikaitkan dengan kulitas fisik permukiman. PT. Perkebunan Nusantara II merupakan suatu perusahaan perkebunan milik pemerintah yang mana mempunyai 5 distrik perkebunan salah satunya adalah Desa Bandar Klippa yang termasuk kedalam Distrik Perkebunan Tahunan Kelapa Sawit dan Karet rayon Selatan.Sebagian lahan milik PT. Perkebunan Nusantara II tidak difungsikan sebagai lahan perekebunan untuk sementara waktu sehingga menjadikan lahan itu kosong.Dusun IV Lamtoro II RT. $\mathrm{V}$ merupakan salah satu daerah permukiman liar yang mana lokasi ini milik PT. Perkebunan Nusantara II, tetapi sebagian lahan milik pemerintah ini tidak dikelola untuk lahan perkebunan Kelapa Sawit dan Karet sehingga lahan tersebut diambil alih oleh organisasi masyarakat yang menguasai daerah tersebut dan lahan itu secara tidak langsung menjadi lahan milik organisasi masyarakat itu.

Adapun yang menjadi tujuan penelitian dalam penelitian ini adalah untuk mengetahui: (1) Legalitas lahan di Dusun IV Lamtoro II RT. V Desa Bandar Klippa Kecamatan Percut Sei Tuan; (2) Kualitas fisik permukiman di Dusun IV Lamtoro II RT. V Desa Bandar Klippa Kecamatan Percut Sei Tuan.

\section{METODE PENELITIAN}

Penelitian ini berlokasi di Dusun IV Lamtoro II RT. V Desa Bandar Klippa Kecamatan Percut Sei Tuan. Adapun alasan penulis mengambil daerah ini sebagai lokasi penelitian adalah pertimbangan sebagai berikut:

1. Pada daerah ini belum pernah dilakukan penelitian dengan topic permasalahan yang sama

2. $\mathrm{Di}$ lokasi tersebut menurut pengamatan sementara terdapat pungutan liar yang dilakukan oleh sekelompok masyarakat tehadap penduduk setempat.

Populasi dalam penelitian ini adalah Dusun IV Lamtoro II RT. V Desa Bandar Klippa Kecamatan Percut Sei Tuan.Teknik pengambilan sampel adalah dengan mengambil 10\% dari jumlah KK yang bermukim disana. Variable dalam penelitian ini adalah legalitas permukiman dan kualitas permukiman

Untuk memperoleh data yang dibutuhkan dalam penelitian ini maka penulis menggunakan teknik pengumpulan data sebagai berikut:

1. Observasi

Teknik pengumpulan data dengan menggunakan pengamatan langsung pada lokasi permukiman liar. Dalam hal ini pengamatan dilakukan untuk melihat kualitas permukiman penduduk di lokasi permukiman liar.

\section{Wawancara}

Teknik pengumpulan data dengan menanyakan langsung kepada masyarakat ataupun penduduk sekitar lokasi permukiman liar terkait dengan legalitas lahan dan kualitas fisik permukiman yang meliputi bangunan rumah, fasilitas rumah, lingkungan rumah, kesehatan lingkungan dan keindahan arsitektural.

Tabel 1. Aspek dan Karakteristik Penilaian Rumah

\begin{tabular}{|c|c|l|}
\hline No & Aspek & \multicolumn{1}{c|}{ Karakteristik } \\
\hline 1 & Bangunan Rumah & $\begin{array}{l}\text { Pondasi Rumah, Tiang Utama, Lantai, } \\
\text { Dinding, Atap Rumah, Penyangga Atap, } \\
\text { Langit-langit, Pintu, Jendela }\end{array}$ \\
\hline 2 & Fasilitas Rumah & $\begin{array}{l}\text { Kamar Tidur, Ruang Tamu, Ruang Makan, } \\
\text { Dapur, Teras Rumah, Kamar Mandi, }\end{array}$ \\
\hline
\end{tabular}




\begin{tabular}{|c|c|l|}
\hline No & \multicolumn{1}{|c|}{ Aspek } & \multicolumn{1}{|c|}{ Karakteristik } \\
\hline & & $\begin{array}{l}\text { WC/Kakus, Letak WC dan Kamar Mandi, } \\
\text { Sumber Air Bersih, Sumber Penerangan } \\
\text { Buatan }\end{array}$ \\
\hline 3 & Lingkungan Rumah & $\begin{array}{l}\text { Halaman Rumah, Pagar Rumah, Pintu } \\
\text { Pagar, Penggenangan Air Hujan, Kondisi } \\
\text { Jalan Kampung }\end{array}$ \\
\hline 4 & Kesehatan Lingkungan & $\begin{array}{l}\text { Pembuangan Limbah Air, Pembuangan } \\
\text { Kakus, Pembuangan Sampah, Penerangan } \\
\text { Alami, Ventilasi, Taman }\end{array}$ \\
\hline 5 & Keindahan Arsitektural & $\begin{array}{l}\text { Lantai, Dinding, Langit-langit, Pintu, } \\
\text { Jendela, Penataan Ruang Dalam }\end{array}$ \\
\hline
\end{tabular}

Sumber: Peraturan Menteri PUPR No.2 Tahun 2016

Teknik analisis data yang digunakan dalam penelitian ini adalah teknik analisis deskriptif kualitatif yaitu mengumpulkan, menganalisis menafsirkan serta memberikan penilaian terhadap kondisi fisik wilayah yang dikategorikan kedalam tiga kategori yaitu sebagai berikut:

Tabel 1. Kategori Fisik Wilayah

\begin{tabular}{|c|c|c|}
\hline No. & Jenis Permukiman & Skor \\
\hline 1. & Permukiman Elit & $102-133$ \\
\hline 2. & Perkampungan Kota & $69-101$ \\
\hline 3. & Permukiman Kumuh & $36-68$ \\
\hline
\end{tabular}

\section{HASIL DAN PEMBAHASAN}

Letak Geografis dan Batas Administrasi Secara geografis Kecamatan Percut Sei Tuan berada di Kabupaten Deli Serdang dan batas administratif wilayah Kecamatan Percut Sei Tuan berbatasan dengan beberapa kecamatan yang ada di Kota Medan dan berbatasan juga dengan Kecamatan Labuhan Deli dan Kecamatan Batang Kuis.

1. Sebelah Utara berbatasan dengan Selat Malaka

2. Sebelah Selatan berbatasan dengan Kota Medan

3. Sebelah Timur berbatasan dengan Kecamatan Batang Kuis dan Kecamatan Pantai Labu

4. Sebelah Barat berbatasan dengan Kota Medan dan Kecamatan Medan Labuhan Deli.
Luas wilayah Kecamatan Percut Sei Tuan adalah $190,79 \mathrm{Km}^{2}$ yang terdiri atas 18 desa, 2 kelurahan, 230 dusun, dan 24 lingkungan dengan ibukota kecamatan adalah Desa Tembung. Desa yang memiliki luas wilayah administrative terbesar adalah Desa Saentis memiliki luas $24,00 \mathrm{Km}^{2}$, sedangkan wilayah dengan luas terkecil adalah Kelurahan Kenangan Baru yang memiliki luas $0,72 \mathrm{Km}^{2}$.

Topografi lahan baik lahan sawah maupun darat rata-rata datar dengan kemiringan kurang dari $5 \%$ dan berjenis tanah alluvial, kondisi tanah di Kecamatan Percut Sei Tuan, memiliki bentuk wilayah yang landai (dataran rendah) dengan ketinggian 0-20 meter diatas permukaan laut. Secara teknis kondisi lahan tersebut dapat memberikan kemudahan bagi sector Perdagangan dan Jasa Perindustrian maupun Permukiman.

Kondisi iklim yang terdapat di Kecamatan Percut Sei Tuan adalah iklim tropis dan memiliki musim hujan dan musim kemarau, cuaca suhu udara Kecamatan Percut Sei Tuan pada umumnya panas dan sedang. Sedangkan untuk curah hujan $2330 \mathrm{~mm} /$ tahun dengan bulan kering kurang dari 3 bulan dan digolongkan Tipe D1 Oldeman, dan mengenai suhu udara adalah $27^{\circ} \mathrm{C}$ hingga $33^{\circ} \mathrm{C}$ dan kelembaban udara $75 \%-80 \%$.

Struktur penduduk menurut jenis kelamin di Kecamatan Percut Sei Tuan diketahui bahwa jumlah penduduk laki-laki lebih banyak dibandingkan jumlah 
penduduk perempuan.Jumlah penduduk laki-laki di Kecamatan Percut Sei Tuan yaitu 203.860 jiwa, sedangkan jumlah penduduk perempuan yaitu 201.710.Struktur penduduk di Kecamatan Percut Sei Tuan menganut berbagai macam agama, diantaranya terdapat pemeluk Agama Islam, Katolik, Protestan, Hindhu/Buddha.Kecamatan Percut Sei Tuan memiliki penduduk dengan mayoritas pemeluk Agama Islam dengan jumlah 349.184 jiwa.

Fasilitas umum merupakan bentuk pelayanan masyarakat yang bertujuan untuk memberikan kemudahan masyarakat dalam melakukan aktifitas kehidupan masyarakat dalam melakukan aktifitas kehidupan sehari-hari. Adapun fasilitas umum yang terdapat di Kecamatan Percut Sei Tuan antara lain, sarana pendidikan, sarana kesehatan dan sarana ibadah.

Untuk menujang kualitas sumber daya manusia, maka keberadaan fasilitas pendidikan merupakan salah satu faktor terpenting dalam usaha pengembangan pendidikannya.Selain itu ketersediaan informasi penyebaran fasilitas pendidikan dapat dijadikan sebagai dasar dalam menilai sejauh mana tingkat kemajuan suatu daerah. Pendidikan merupakan sarana dalam usaha mencerdaskan bangsa dan Negara, menciptakan generasi muda dan sumber daya manusia yang siap pakai dalam pembangunan bangsa pada masa yang akan datang. Berhasilnya suatu pembangunan tidak terlepas dari tingkat pendidikan, dimana semakin maju tingkat pendidikan berarti akan membawa dampak yang positif bagi masa depan dalam berbagai ilmu kehidupan.

Perkembangan pendidikan di Kecamatan Percut Sei Tuan memuat data SD, SMP, SMA dan setingkatnya, baik yang dikelola Dinas Pendidikan maupun diluarnya yang menyebar seluruh Kecamatan Percut Sei Tuan, sedangkan untuk Perguruan Tinggi/Akademi dikelola pihak swasta, dan untuk sarana pendidikan di Desa Bandar Klippa terdapat 6 unit TK, 18 unit SD, 6 unit SMP, dan 3 unit SMA.
Sarana kesehatan diperlukan untuk menunjang derajat kesehatan masyarakat di wilayah Kecamatan Percut Sei Tuan. Penyebaran sarana dan juga tenaga medis kesehatan medis kesehatan bagi kebutuhan penduduk jumlah memadai, dimana saran kesehatan yang terdapat di Kecamatan Percut Sei Tuan antara lain puskesmas pemerintah, praktek bidan swasta, poliklinik, puskesmas pembantu, balai pengobatan dan klinik swadaya.

Tabel 3. Jumlah Sarana Kesehatan di Kecamatan Percut Sei Tuan Tahun 2015

\begin{tabular}{|c|c|}
\hline Sarana Kesehatan & Jumlah (Unit) \\
\hline Rumah Sakit & 5 \\
\hline Poliklinik/Balai Pengobatan & 38 \\
\hline Puskesmas & 3 \\
\hline Puskesmas Pembantu & 10 \\
\hline
\end{tabular}
Sumber: Kecamatan Percut Sei Tuan Dalam Angka Tahun 2015

Untuk sarana kesehatan yang terdapat di Desa Bandar Klippa adalah 6 unit klinik, 1 unit Rumah Sakit, 3 unit Puskesmas Pembantu.

Pembangunan dibidang keragaman di Kecamatan Percut Sei Tuan selalu mendapatkan perhatian baik dari Pemerintah maupun swasta.Jumlah fasilitas peribadatan di Kecamatan Percut Sei Tuan dipengaruhi oleh jumlah penganut masingmasing agama.

Tabel 4. Jumlah Sarana Ibadah di Kecamatan Percut Sei Tuan Tahun 2015

\begin{tabular}{|c|c|}
\hline Sarana Ibadah & Jumlah (Unit) \\
\hline Mesjid & 175 \\
\hline Mushollah & 166 \\
\hline Gereja & 75 \\
\hline Kuil/Pura & 1 \\
\hline Vihara & 7 \\
\hline
\end{tabular}

Sumber: Kecamatan Percut Sei Tuan Dalam Angka Tahun 2015

Sedangkan untuk sarana ibadah terdapat 27 unit masjid, 25 unit mushollah, 10 unit gereja dan 1 unit vihara.

Sarana jalan merupakan salah satu faktor penentu percepatan pembangunan, 
kondisi jaringan jalan yang baik dapat menjadi modal dalam memperlancar kegiatan perhubungan, ekonomi dan transportasi.Kecamatan Percut Sei Tuan memiliki jenis jaringan jalan kabupaten, jalan dusun dan jalan setapak, Sedangkan untuk panjangnya jalan terdapat $24.50 \mathrm{~km}$ jalan beraspal, $15.65 \mathrm{~km}$ jalan kerikil, dan $15.25 \mathrm{~km}$ jalan tanah.

Tabel 5. Kondisi Panjang Jalan Berdasarkan Jenisnya di Kecamatan Percut Sei Tuan

\begin{tabular}{|c|c|}
\multicolumn{2}{|c}{2015} \\
\hline Jenis Jalan & Panjang (Km) \\
\hline Aspal & 196.05 \\
\hline Kerikil & 125.31 \\
\hline Tanah & 121.93 \\
\hline Beton & 14.35 \\
\hline
\end{tabular}

Sumber: Kecamatan Percut Sei Tuan Dalam Angka Tahun 2015

Sarana penghubung jalan yang memiliki peran penting adalah sarana jembatan penghubung yang berfungsi menyatukan jaringan jalan yang terpisah oleh kondisi bentang alam seperti pada umumnya aliran sungai, saluran drainase dan jaringan irigasi.Kecamatan Percut Sei Tuan terdapat beberapa jenis sarana jembatan penghubung.

\section{Kegiatan Perekonomian}

Faktor utama yang dapat mendukung penduduk dan memberdayakan masing-masing individu untuk dapat bertempat tinggal di suatu wilayah adalah dari kegiatan perekonomiannya. Dengan perkataan lain, keberadaan penduduk di suatu wilayah baik perkotaan maupun perdesaan dimungkinkan dengan adanya pekerjaan dan tenaga kerja di wilayah yang bersangkutan. Dengan demikian terdapat keterkaitan yang erat antara tingkat perekonomian dengan tingkat populasi di suatu wilayah.

\section{Kegiatan Pertanian}

Kegiatan Pertanian di Kecamatan Percut Sei Tuan didukung oleh tersedianya lahan pertanian dan juga jaringan irigasi yang merupakan bagian dari aktifitas pertanian.Sector pertanian memberikan kontribusi besar bagi perkembangan ekonomi masyarakat Kecamatan Percut Sei Tuan khususnya yang bertani dan memberikan pengaruh besar terhadap perkembangan ekonomi daerah Kabupaten Deli Serdang secara umum.Pertanian yang terdapat di Kecamatan Percut Sei Tuan terdiri atas persawahan dan dataran kering.Kegiatan pertanian melalui adanya ketersediaan lahan pertanian yang terdapat di Kecamatan Percut Sei Tuan diperoleh hasil produksi Percut Sei Tuan diperoleh hasil produksi pertanian yang telah dikerjakan oleh petani.

\section{Kegiatan Perindustrian}

Kecamatan Percut Sei Tuan terdapat sector industri yang turut juga mendukung perekonomian Kegiatan Percut Sei Tuan, adapun sector industri yang terdapat di Kecamatan Percut Sei Tuan terdiri dari industri besar, industri sedang dan industri kecil dan kerajinan rumah tangga. Kegiatan industri yang dominan terdapat di Kecamatan Percut Sei Tuan adalah kerajinan rumah tangga dengan jumlah 246 industri kerajinan rumah tangga, Sedangkan untuk perindustrian di Desa Bandar Klippa terdapat 10 unit Industri Besar, 8 unit Industri Menengah, 25 unit Industri Kecil dan 53 unit Industri Rumah Tangga.

Tabel 6. Banyaknya Industri Berdasarkan Jenisnya Tahun 2015

\begin{tabular}{|c|c|}
\hline Jenis Industri & Banyaknya (Unit) \\
\hline Industri Besar & 84 \\
\hline Industri Menengah & 62 \\
\hline Industri Kecil & 165 \\
\hline $\begin{array}{c}\text { Industri Rumah } \\
\text { Tangga }\end{array}$ & 408 \\
\hline Jumlah & 719 \\
\hline
\end{tabular}

3. Kegiatan Perternakan 
Dibidang perternakan, Kecamatan

Percut Sei Tuan memiliki produksi komoditi perternakan yang dapat diandalkan terhadap ketersediaan bahan pangan.Kecamatan Percut Sei Tuan serta menjadi salah satu penyuplai bahan pangan terhadap Kota Medan, Untuk kegiatan perternakan di Desa Bandar Klippa terdapat 496 ekor sapi, 48 ekor kerbau, 900 ekor kambing, 655 ekor domba, 67 ekor babi, 1620 ekor itik dan 5861 ekor ayam.

Tabel 7. Banyaknya Ternak di Kecamaan Percut Sei Tuan Tahun 2015

\begin{tabular}{|c|c|}
\hline Jenis Komoditi & Banyaknya (Ekor) \\
\hline Sapi Biasa & 3.961 \\
\hline Sapi Perah & 4 \\
\hline Kerbau & 384 \\
\hline Kambing & 7.498 \\
\hline Domba & 5.248 \\
\hline Babi & 540 \\
\hline Ayam Ras & 58.329 \\
\hline Itik & 16.166 \\
\hline
\end{tabular}

Sumber: Kecamatan Percut Sei Tuan Dalam Angka Tahun 2015

\section{Permasalahan Permukiman Liar}

Kondisi dan kualitas permukiman di

Desa Bandar Klippa memiliki kondisi fisik yang tidak memenuhi persyaratan kesehatan yang mana kurangnya tersedia prasarana fasilitas dan utilitas lingkungan seperti kondisi letak sumur yang rata dengan tanah sehingga jika air hujan mengalir maka akan masuk kedalam sumur tersebut. Kondisi bangunan yang tidak teratur karena tidak direncanakan terlebih dahulu serta bahan-bahan bangunan yang bersifat tidak permanen.Faktor pendorong masyarakat bertempat tinggal di lokasi permukiman liar disebabkan oleh beberapa faktor diantaranya kepadatan penduduk yang tinggi sehingga banyak masyarakat yang tidak dapat untuk membangun rumah dikarenakan lahan yang tidak memadai dan memilih untuk membangun rumah di lahan illegal milik pemerintah tersebut.Kemudian dengan harga lahan yang murah menyebabkan banyak masyarakat yang tergiur untuk membelinya dan tidak mementingkan lahan itu illegal dan membangunnya untuk dijadikan tempat tinggal. Selain itu masih banyak masyarakat yang kurang mampu tidak mampu untuk mengontrak rumah di daerah kota karena harga sewa yang semakin tinggi sehingga mencari rumah kontrakan di permukiman liar dikarenakan harga sewa yang murah.

Desa Bandar Klippa secara administrative berbatasan dengan Kota Medan, tepatnya pada Kecamatan Medan Denai dan Medan Tembung.Sedangkan lokasi permukiman liar yang sedang dibahas diantara perbatasan dengan Medan Denai tepatnya di Dusun IV Lamtoro II RT. V Desa Bandar Klippa Pasar III Tembung Kec.Percut Sei Tuan.RT. V Dusun IV Lamtoro II merupakan salah satu lokasi yang berada di atas lahan PT. Perkebunan Nusantara II yang mana lokasi ini termasuk ke dalam Distrik Tanaman Tahunan Kelapa Sawit dan Karet Rayon Selatan.

Lahan PT. Perkebunan Nusantara II di sekitar lokasi penelitian yaitu RT. V Dusun IV Lamtoro II telah lama tidak difungsikan sebagai lahan perkebunan sehingga lahan kosong tersebut dimanfaatkan oleh masyarakat sebagai lokasi permukiman dan siapa saja bisa membangun rumah di area lahan milik PT. Perkebunan Nusantara II tersebut dan lahan yang ditempati oleh masyarakat tersebut tidak mempunyai surat tanah yang jelas sehingga disini organisasi masyarakat terlibat dimana organisasi masyarakat memiliki wilayah kekuasaan yang mana lahan milik PT. Perkebunan Nusantara II yang telah lama tidak difungsikan itu masuk ke wilayah kekuasaan mereka dan mereka mengolah lahan kosong yang telah lama tidak difungsikan itu menjadi sumber pemasukan mereka. Lahan kosong milik PT. Perkebunan Nusantara Ilkini diolah oleh organisasi masyarakat yang mana lahan tersebut diperjual belikan kepada masyarakat dengan harga yang murah. 
Seiring dengan berjalannya waktu maka satu per satu lahan yang dijadikan sebagai ladang tersebut berubah menjadi permukiman, dan kini mayoritasnya ladang milik masyarakat itu berubah menjadi permukiman.Sebagian masyarakat membangun rumah untuk tempat tinggal pribadi tetapi tidak sedikit pula masyarakat membangun rumah untuk disewakan agar mendapatkan keuntungan dari hasil sewa tersebut.

Menurut pengakuan dari masyarakat, jika kita ingin membeli tanah di lahan ini maka kita harus menemui ketua di lahan tersebut yang merupakan salah satu pimpinan cabang di organisasi masyarakat tersebut. Selanjutnya ketua tersebut akan menawarkan beberapa lahan kosong yang akan kita beli dengan harga yang murah, lalu bernegosiasi ataupun melakukan transaksi pembayaran dengan ketua itu, dan uang hasil pembelian tanah itu menjadi pemasukan untuk ketua. Artinya, lahan kosong milik PT. Perkebunan Nusantara II yang telah lama tidak difungsikan itu dimanfaatkan oleh sekelompok orang untuk mencari keuntungan dan semua lahan kosong pemerintah yang tidak digunakan itu bebas diperjual belikan oleh pihak organisasi masyarakat yang menguasai daerah itu, sehingga secara tidak langsung lahan kosong itu menjadi milik mereka dan bebas menjualnya kepada siapa saja.

Ada peraturan yang dibuat oleh

Ketua Organisasi Masyarakat yang berkuasa di lahan itu, yang mana setiap masyarakat yang membeli lahan itu wajib membangun bangunan atau menanam tanaman di lahannya masing-masing, jika tidak maka ketua itu berhak mengambil alih lahan yang telah dibeli masyarakat dan menjualnya kembali kepada orang lain. Begitu juga dengan bangunan yang tidak ditempati, jika terdapat bangunan di lahan itu dan tidak ditempati maka lahan tersebut juga akan diambil alih oleh ketua. Tetapi ada beberapa lahan yang tidak diambil alih oleh ketua yang mana jika pembelinya adalah seorang polisi ataupun
TNI maka lahan yang dibeli tersebut tidak diambil oleh ketua karena jika diambil alih maka urusannya akan sampai ke jalur hukum.

Masyarakat yang diambil alih lahannya tidak bisa menuntut apa-apa karena lahan itu tidak dilengkapi dengan surat tanah, yang ada hanya kwitansi dan kesepakatan yang diperbuat oleh kedua belah pihak. Dan jika mereka menuntut kepada pihak yang berwajib mereka malas untuk mengikuti prosedur hukum yang jalannya cukup panjang dan tidak mempunyai bukti yang kuat untuk menuntutnya sehingga daripada mereka bertahan lebih baik mereka mundur.Bukan itu saja, organisasi masyarakat yang mendiami lahan pemerintah itu cukup banyak sehingga daripada mencari pertengkaran dengan anggota organisasi masyarakatlebih baik mereka pergi dari lahan itu. Selain itumenurut pernyataan dari beberapa responden, ketua organisasi masyarakat yang menguasai lahan pemerintah itu sering ditangkap oleh polisi karena beberapa pengaduan yang dilaporkan masyarakat terkait penjualan lahan illegal, tetapi tidak pernah ditahan oleh polisi karena ketua memiliki relasi dengan beberapa oknum polisi yang istilahnya "orang dalam" sehingga kegiatan yang ia lakukan tidak sampai berujung penjara.

Ketua organisasi masyarakat yang menguasai lahan pemerintah itu juga memiliki relasi yang kuat dengan PLN, yang mana beberapa rumah masyarakat yang tidak memiliki meteran listrik di fasilitasi oleh organisasi masyarakat sebagai pengelola lahan illegal itu untuk memasukkan arus listrik ke setiap rumah yang tidak memiliki meteran listrik dengan cara mencuri arus dan kemudian setiap rumah yang tidak memiliki meteran listrik harus membayar iuran untuk listrik sebesar 30 ribu per bulannya. Dan aksi ini tidak pernah ketahuan oleh PLN karena telah diberi uang "tutup mulut" kepada petugas lapangan. Di lokasi ini juga terdapat ronda kampung atau tugas jaga malam yang 
gunanya untuk mengantisipasi hal-hal yang tidak diinginkan seperti kemalingan dan sebagainya, awalnya setiap kepala keluarga dilibatkan untuk mengikuti ronda ini agar komunikasi terjalin satu sama lain dan setiap kepala keluarga diberi giliran sekali sebulan, tetapi banyak masyarakat yang berhalangan atau tidak dapat mengikuti ronda tersebut dikarenakan sibuk kerja sehingga dikenakan biaya sebesar 15 ribu per bulannya.

\section{Kondisi Permukiman}

Permukiman liar di Dusun IV Lamtoro II RT.V ini mayoritasnya dihuni oleh masyarakat yang berpenghasilan menengah ke bawah yang mana mereka tidak mampu untuk membeli rumah atau pun tanah sehingga memanfaatkan lahan pemerintah sebagai lokasi tempat tinggal dengan harga lahan yang murah.Di samping itu juga banyak masyarakat yang berpenghasilan menengah ke bawah tidak mampu untuk menyewa rumah di daerah perkotaan dikarenakan harga sewa yang semakin mahal sehingga mencari rumah kontrakan ke lahan illegal ini dengan harapan harga rumah yang murah.Permukiman liar di Dusun IV Lamtoro II RT. V dihuni oleh sekitar 300 Kepala Keluarga dengan kondisi rumah yang terkesan kumuh dan kondisi jalan yang masih belum beraspal dan bergelombang membuat jalan begitu licin ketika hujan dan tergenang air sehingga tak jarang lokasi permukiman liar ini akan banjir jika hujan lebat mengguyur daerah ini. Kami telah mengobservasi 10\% dari total Kepala Keluarga untuk melihat kondisi, kualitas rumah dan lingkungannya.

$$
\text { Menurut }
$$

UN-HABITAT menetapkan 5 indikator permukiman kumuh. Permukiman di perkotaan yang disebut kumuh paling sedikit mengandung keterbatasan pada salah satu dari lima keadaan berikut:

1. Akses mendapatkan air bersih yang baik

2. Akses mendapatkan fasilitas sanitasi yang baik

3. Area/ruang tempat tinggal yang cukup, tidak terlalu padat

4. Hunian dengan struktur yang tahan lama

5. Mata pencaharian yang aman.

Dari 30 responden yang telah di observasi, masih banyak rumah dari masyarakat misalnya, tidak mempunyai kamar mandi atau sumber air yang digunakan kotor dan berbau.Di samping itu kondisi lingkungan yang tidak terawat juga dapat menyebabkan timbulnya penyakit.Kami mengumpulkan hasil dari pengamatan berdasarkan penilaian dari lembar observasi sehingga dapat disimpulkan keadaan berdasarkan kondisi fisik dari 30 responden masih tergolong dalam Permukiman Kumuh, sehingga lokasi Dusun IV Lamtoro II RT. V bukan saja termasuk ke dalam permukiman liar tetapi berdasarkan kondisi fisik yang diamati permukiman ini juga tergolong kedalam permukiman kumuh yang bias dibuktikan salah satunya melalui akses air bersih dan sanitasi yang kurang baik.

Peraturan Menteri PUPR No.2 Tahun 2016 dimaksudkan menjadi acuan dalam penyelenggaraan peningkatan kualitas terhadap permukiman yang bertujuan untuk meningkatkan mutu kehidupan dan penghidupan masyarakat penghuni permukiman kumuh. Hasil observasi kondisi permukiman dapat dilihat pada Tabel 8 dan 9 berikut.

Tabel 8. Hasil Observasi Kondisi Permukiman

\begin{tabular}{|c|l|c|c|c|c|c|c|c|}
\hline No & \multicolumn{1}{|c|}{$\begin{array}{c}\text { Nama } \\
\text { Responden }\end{array}$} & Bangunan & $\begin{array}{c}\text { Fasil } \\
\text { itas }\end{array}$ & $\begin{array}{c}\text { Lingk. } \\
\text { Rumah }\end{array}$ & $\begin{array}{c}\text { Kesehatan } \\
\text { Lingk. }\end{array}$ & $\begin{array}{c}\text { Arsitek } \\
\text { tural }\end{array}$ & Jlh & Gol \\
\hline 1 & Suwarni Tanjung & 27 & 21 & 7 & 7 & 6 & 68 & 3 \\
\hline 2 & Hendrik Yunus & 28 & 29 & 8 & 7 & 7 & 79 & 2 \\
\hline 3 & Eli Ningsih & 23 & 23 & 7 & 6 & 5 & 64 & 3 \\
\hline
\end{tabular}




\begin{tabular}{|c|l|c|c|c|c|c|c|c|}
\hline No & \multicolumn{1}{|c|}{$\begin{array}{c}\text { Nama } \\
\text { Responden }\end{array}$} & Bangunan & $\begin{array}{c}\text { Fasil } \\
\text { itas }\end{array}$ & $\begin{array}{c}\text { Lingk. } \\
\text { Rumah }\end{array}$ & $\begin{array}{c}\text { Kesehatan } \\
\text { Lingk. }\end{array}$ & $\begin{array}{c}\text { Arsitek } \\
\text { tural }\end{array}$ & Jlh & Gol \\
\hline 4 & Syaiful Rizan & 25 & 23 & 7 & 6 & 6 & 67 & 3 \\
\hline 5 & Analia Piliang & 31 & 27 & 9 & 7 & 7 & 83 & 2 \\
\hline 6 & Rabbani Daulay & 29 & 28 & 9 & 7 & 7 & 80 & 2 \\
\hline 7 & Juli Sofia & 31 & 27 & 9 & 7 & 6 & 81 & 2 \\
\hline 8 & Junaedi Silaban & 25 & 21 & 7 & 6 & 6 & 65 & 3 \\
\hline 9 & Yanti Chaniago & 32 & 28 & 7 & 7 & 7 & 81 & 2 \\
\hline 10 & Arif Rahmat & 30 & 27 & 8 & 7 & 6 & 78 & 2 \\
\hline 11 & Rini Debby Astuti & 27 & 21 & 7 & 7 & 6 & 68 & 3 \\
\hline 12 & Ichavina Azriel & 24 & 21 & 7 & 7 & 6 & 65 & 3 \\
\hline 13 & Joel Reza Situmorang & 30 & 28 & 8 & 7 & 7 & 80 & 2 \\
\hline 14 & Fitra Rizky & 37 & 29 & 9 & 7 & 7 & 89 & 2 \\
\hline 15 & Revania Wiryono & 26 & 21 & 7 & 7 & 6 & 67 & 3 \\
\hline 16 & Adryan Pratama & 32 & 28 & 8 & 7 & 7 & 82 & 2 \\
\hline 17 & Fachriansyah Putra & 30 & 29 & 8 & 7 & 7 & 81 & 2 \\
\hline 18 & Irdham Gunawan & 29 & 28 & 7 & 7 & 7 & 78 & 2 \\
\hline 19 & Johan Ali & 22 & 22 & 7 & 6 & 6 & 63 & 3 \\
\hline 20 & Nur Fitri Yana & 26 & 22 & 7 & 6 & 6 & 63 & 3 \\
\hline 21 & Ani Syamsidar & 24 & 21 & 8 & 6 & 6 & 65 & 3 \\
\hline 22 & Daniel Mawuntu & 27 & 20 & 7 & 6 & 6 & 66 & 3 \\
\hline 23 & Tiara Sartika Putri & 37 & 29 & 8 & 7 & 7 & 88 & 2 \\
\hline 24 & Siti Zakia Fatimah & 25 & 23 & 8 & 6 & 6 & 66 & 3 \\
\hline 25 & Ratna Sarahayu & 23 & 21 & 7 & 6 & 6 & 63 & 3 \\
\hline 26 & Ricky Roniagam & 26 & 26 & 8 & 7 & 6 & 73 & 2 \\
\hline 27 & Baridho Rio Hutapea & 24 & 22 & 7 & 6 & 6 & 65 & 3 \\
\hline 28 & Irsan Parluhutan Tua & 32 & 28 & 9 & 7 & 7 & 83 & 2 \\
\hline 29 & Laely Nurlela & 30 & 27 & 8 & 5 & 6 & 76 & 2 \\
\hline 30 & Ummi Kalsum & 28 & 24 & 7 & 6 & 6 & 67 & 3 \\
\hline $54 m$ & & & & & & \\
\hline
\end{tabular}

Sumber: Hasil Penelitian, 2016

Tabel 9. Rekapitulasi Kondisi Permukiman

\begin{tabular}{|c|c|c|c|}
\hline No. & Jenis Permukiman & Skor & Jumlah \\
\hline 1. & Permukiman Elit & $102-133$ & 0 \\
\hline 2. & Perkampungan Kota & $69-101$ & 15 \\
\hline 3. & Permukiman Kumuh & $36-68$ & 15 \\
\hline
\end{tabular}

Sumber: Hasil Penelitian, 2016

Berdasarkan kualitas rumah dan lingkungan, maka di daerah Dusun IV Lamtoro II RT. V terdapat 15 dari 30 rumah dengan golongan Perkampungan Kota serta 15 dari 30 rumah dengan golongan Permukiman Kumuh. Berdasarkan hasil tersebut jika di analisis masyarakat yang mempunyai rumah dengan golongan Perkampungan Kota atau dengan skor diatas 80 rata-rata mereka adalah masyarakat yang mempunyai jabatan sebagai alat Negara dan rumah mereka tergolong berada dalam kondisi baik.

\section{KESIMPULAN DAN SARAN \\ Kesimpulan}

Permukiman adalah bagian dari lingkungan hidup diluar kawasan lindung yang dapat merupakan kawasan perkotaan 
dan perdesaan yang berfungsi sebagai lingkungan tempat tinggal atau hunian dan tempat kegiatan yang mendukung penghidupan.

Permukiman liar adalah tempat bermukim suatu penduduk yang tidak memiliki keteraturan menurut aturan dan tanpa izin resmi dari yang berwenang. Rendahnya tingkat pendapatan dan pendidikan pada masyarakat perdesaan memang mempunyai pengaruh yang sangat luas terhadap perilaku sosial, ekonomi, dan budaya. Hal ini tentu saja juga akan sangat berpengaruh terhadap tingkat kualitas perumahan penduduk.

\section{Saran}

Seharusnya kasus permukiman sudah bisa ditangani salah satu cara yaitu dengan menegakkan keadilan dan mmeperkuat hukum misalnya, pemberian sanksi terhadap masyarakat yang menggunakan lahan pemerintah tanp izin. Selain itu juga pemberantasan oknum yang tidak bertanggung jawab yang mengelola lahan pemerintah demi mendapatkan keuntungan.

Untuk mengatasi kekumuhan pada permukiman kumuh illegal dapat ditempuh melalui dua cara:

1. Untuk lahan permukiman liar (ilegal) yang masih banyak ditolerir sebagai lahan permukiman dapat dilakukan "pemutihan" yaitu mengubah status lahan dari illegal menjadi legal, yang kemudian dapat diikuti oleh aplikasi KIP atau Peremajaan permukiman.

2. Untuk lahan permukiman liar (illegal) yang sama sekali tidak dapat ditolerir sebagai lahan permukiman, dapat dilakukan pengosongan atau mengembalikan lahan pada fungsi semula. Walaupun demikian cara ini hendaknya dilakukan secara manusiawi yaitu dengan memberikan berbagai alternative yang dapat ditawarkan kepada para pemukim tersebut adalah relokasi, transmigrasi, pemulangan kembali ke daerah asal dang anti rugi.

\section{DAFTAR PUSTAKA}

Abadi, T. W., \& Mahendrawati, I. K. (2012). Penertiban Versus Penggusuran: Strategi Komunikasi dan Partisipasi Pembangunan (Studi Kasus di Stren Kali Jagir WonokromoSurabaya). Scriptura, 3(2), 112-128.

Judohusodo, S. (1991). Tumbuhnya Permukiman-Permukiman Liar tiddi Kawasan Perkotaan. JIIS. Nomor, 1.

Pinem, M. (2010). Pengaruh Sosial Ekonomi Terhadap Kualitas Permukiman di Kelurahan Sidorejo Kecamatan Medan Tembung Kota Medan. JURNAL GEOGRAFI, 2(2), 71-80.

Pinem, M. (2011). Persebaran Permukiman Kumuh Di Kota Medan. JURNAL GEOGRAFI, 3(1), 27-38.

Ridhlo, M. A. (2002). Karakteristik Kemiskinan Perkotaan pada Permukiman Kumuh dan Liar Kota Semarang." (Doctoral dissertation, Tesis tidak diterbitkan, Program Studi Magister Teknik Pembangunan Kota, Program Pasca Sarjana Universitas Diponegoro, Semarang).

Soesilowati, E. (2007). Kebijakan Perumahan Dan Permukiman Bagi Masyarakat Urban. Dinamika, 16(1).

\footnotetext{
Yunus, Hadi Sabari. 1987. Geografi Permukiman Dan Beberapa Masalah. Permukiman Kota. Yogyakarta : Fakultas Geografi, Universitas Gadjah. Mada
} 